\title{
The Assessment of Organizational Strengths, Weaknesses, Opportunities, and Threats of Zakat Distribution Organizations in Malaysia
}

\author{
Shukran Abd. Rahman, Muhammad Haikal Ahmad Pua'ad \\ Kulliyyah of Islamic Revealed Knowledge and Human Sciences, International Islamic University \\ Malaysia, Kuala Lumpur
}

\section{Mohd Hasnal Atfi Mohd Helmi}

Malaysian Prison Department, Malaysian Minister of Home Affairs, Selangor

\section{Muhammad Rizki Azirwan, Aiman Mohammad, Fatin Fauzi}

Postgraduate Student, Department of Psychology, International Islamic University Malaysia, Kuala Lumpur

\section{Munirah Ahmad Dahari}

School of Business and Management, KPJ Healthcare University College, Negeri Sembilan

\begin{abstract}
There have been emerging issues toward the increasing amount of zakat collection and the slower pace of zakat distribution (Lubis et al., 2011). These issues create dissatisfaction which increases negative perception towards Zakat Distribution Organizations (ZDOs) amongst the zakat payers (Yusof, 2010). The objective of this study is to assess the strengths, weaknesses, opportunities, and threats of ZDOs. The methods used in this study were document analysis and Focus Group Discussion (FGD) conducted among the employees of ZDOs. Findings from this study showed that the strengths are related to the aspects on human resource management, the stable financial sources, the broad network, the good organizations setup, the positive work culture among staff members, as well as opportunities for learning and development for ZDOs employees. The weaknesses of ZDOs are associated with workplace condition, staff members' attitudes and work performance, and management system. In addition, external environment provides a significant opportunity for the organizations. Proactive distribution of zakat and collaboration with other agencies are external aspects that can be leveraged in order to improve the functions of ZDOs. The identified threats are the ZDOs' surrounding, the attitudes of zakat recipients towards ZDOs, competition from outside parties, public dependency, and external interferences. These findings are expected to provide baseline information to guide ZDOs in designing change initiatives that will be effective and efficient in increasing both work and organizational performance.
\end{abstract}

Keywords: opportunities, strengths, threats, weakness, zakat organization

Correspondence: Shukran Abd. Rahman. Email: shukran@iium.edu.my 


\section{Penilaian Kekuatan, Kelemahan, Kesempatan dan Ancaman Organisasional pada Organisasi Distribusi Zakat di Malaysia}

Abstrak. Terdapat kasus adanya kenaikan angka sumbangan zakat, namun distribusi zakat semakin melambat (Lubis et al., 2011). Isu-isu ini menciptakan ketidakpuasan yang menimbulkan persepsi buruk dari penyumbang terhadap Organisasi Distribusi Zakat (ZDO) (Yusof, 2010). Tujuan penelitian ini adalah untuk menilai kekuatan, kelemahan, kesempatan, dan ancaman organisasional ZDO. Metode yang digunakan dalam penelitian ini adalah analisis dokumen dan Focus Group Discussion (FGD) dengan karyawan ZDO. Temuan dari penelitian ini menunjukkan bahwa kekuatan dari organisasi ini terletak pada manajemen sumber daya manusia, sumber penghasilan yang stabil, jaringan yang luas, rancangan organisasi yang baik, budaya kerja karyawan yang positif, dan adanya kesempatan bagi karyawan ZDO untuk belajar dan berkembang. Kelemahan ZDO berkaitan dengan kondisi lingkungan kerja, perilaku dan sikap karyawan serta kinerja dan sistem manajemennya. Tambah lagi, lingkungan eksternal menyediakan kesempatan yang signifikan bagi organisasi. Distribusi zakat yang proaktif dan kolaborasi dengan instansi lain merupakan aspek eksternal yang dapat diperluas untuk mengembangkan fungsi ZDO. Ancaman yang diketahui adalah lingkungan sekitar, sikap penerima zakat, kompetisi dengan lembaga lain, ketergantungn publik dan gangguan eksternal lainnya. Hasil-hasil ini diharapkan dapat memberikan informasi mendasar bagi ZDO untuk melakukan rancangan perubahan, peningkatan dan pengembangan fungsi organisasinya di masa depan.

Kata Kunci: ancaman, kekuatan, kelemahan, kesempatan, Organisasi Distribusi Zakat.

Religious belief and its practices have been acknowledged as important guides that enable individuals and society to manage life and tackle tasked issues in the society (Fagan, 2006). The teachings of Islam encompass the requirement to involve in, and avoid certain behaviors, both overt and covert. These behaviours are essential in attaining quality life among people in the society (Akanni, 2006). Islam places strong emphasis on the need to safeguard the welfare of the society, evident in many of its religious injunctions. Some practices have been made as compulsory, such as giving contributions to those who are in need of assistance after certain requirements have been fulfilled. In this regard, zakat has been made as injunction through which Islam puts in place a mechanism promoting harmonious life in the society; or safeguards the livelihood of individuals who are in need of help.

The term zakat is literally defined as growth, blessing, pure, good and renowned (Johari et al., 2013; Mohammed, 2011; P \& Umah, 2011). The concept of zakat refers to the issuance of certain amount or portion from a specific wealth owned by Muslims to be given to those who are entitled to receive it. Zakat or alms giving is a compulsory contribution from Muslims who have the ability to contribute certain portion of wealth to other people. Since it is stated in Al-Quran that "wealth does not circulate only among the rich" (Al-Hashr: 7) (Johari et al., 2013), it is an obligation upon Muslims to pay specified amount of zakat to eligible recipients (Sarea, 2012). 


\section{Zakat Distribution Organizations (ZDOs)}

ZDOs are tasked with zakat collection activities as well as its distribution. It is expected that the wealth which are collected are not kept idle but being distributed to the deserving parties to ensure that zakat would become a productive fund for societal development (Widiastuti et al., 2018). ZDOs can be categorized as faith-based organizations since they are mainly defined by the values and rules of a religious belief as mentioned by Thomas (2008). (Thomas, 2008).

A faith-based organization (a) carries the obligation to act within the command of a particular religion; (b) facilitates the commitment of members to contribute to others, driven by religious values; (c) source the availability of formal financial support, and lead its administration, by religious authorities or official authorities; and (d) hold the responsibility to help manage and tackle various social issues in the community (Hamilton, 2011).

A faith-based organization which is also synonymous to philanthropic organization is generally the result of private initiative to enhance the roles of local community in contributing towards the benefit of education, community development, the environment, or arts and culture (Hafsi \& Thomas, 2005). In the Western countries, they collect funds from charitable donors to finance community-based projects. In Muslim countries, similar effort is usually associated with the establishment of
ZDOs. Both philanthropic organizations and ZDOs are quite similar in term of their roles. Faith-based organizations are instrumental in dealing with social issues, specifically reducing or alleviating people's hardship and sufferings (Bakar \& Abd.Ghani, 2011).

There are many types of faith-based organizations. In the case of ZDOs, its roles range from collecting zakat to distributing it to the qualified recipients. To date, in Malaysia, there are many faith-based organizations which functions are similar to those of other organizations which are typified as such. Given the similar nature of activities played by ZDOs, it is acceptable to identify ZDOs, like the ones present in Malaysia, as faith-based organization.

ZDOs are expected to play the roles in establishing zakat governance, systematise zakat collection, and manage zakat distribution. However, the most highlighted role of ZDOs is the disbursement of zakat to the deserving groups (Muhammad, 2019). Though various strategies have been implemented to improve the performance of ZDO, the increasingly changing technology and societal structure require the organization to reassess their functions, review the work processes, and understand the expectations of stakeholders. Thus, there is a need to explore the strengths and weaknesses of ZDOs as well as to identify the opportunities to be leveraged or threats to be managed. The information on these aspects is expected to give insights that would enable 
ZDOs to maintain, improve or fully utilize their capacities to achieve their goals; and in turn they become more effective and efficient in their operation.

\section{This study}

Although there are improvements in ZDO as it is reported by Wahid et al (2009) and Muhammad (2019), there have been emerging issues confronting ZDO in Malaysia. Even though the amount of zakat collection increases relatively higher from year to year, the zakat distribution is identified to be at the slower pace (Lubis et al., 2011). A research conducted by Yusof (2010) indicates that zakat management has received the highest level of negative perception amongst the zakat payers (Yusof, 2010). ZDOs in the states of Selangor, Pulau Pinang, and Federal Territory of Kuala Lumpur have recorded the highest level of dissatisfaction from the zakat payers (Wahid et al., 2009).

The dissatisfaction towards ZDOs indicates that there are issues which have lead in their negative perception. The negative perception of ZDOs amongst the public causes the urgency of further attention to be given, especially on the identification of factors that lead to their dissatisfaction; and warrants for a study to identify the weaknesses and the threats they faced. It will in turn help ZDOs to formulate their strategies to change, improve, and develop their organizational performance.
The increasingly changing demographic, economic, and societal factors have confronted ZDOs with many issues that require more attention. The objective of this paper is to obtain an information about the strengths, opportunities, weaknesses, and threats faced by ZDOs. The literature review result revealed that there were not many research were conducted in Malaysia to address the strengths, opportunities and weakness of ZDOs; or to identify issues which serve as threats toward their effective roles in meeting the objectives. The previous researches, such as those done by Yusof (2010) and Wahid, Ahmad, and Kader (2009) addressed the weakness and threat at a surface level, mainly based on ZDOs annual report. Previous studies were superficial therefore there is a need to conduct extensive study on threats and weaknesses.

While there are various complaints on zakat distributions, little effort has been made to properly identify or assess the issues. The current social scenario, characterized by poverty rate that stands in $1.7 \%$ in 2012 (Worldbank, 2015) and the huge number of homeless people in Malaysia (1,500 homeless people in Kuala Lumpur area) (Kong, 2014) reflect that ZDOs may not be performing at its best. ZDOs need to gain sustainability and competitive advantage to be able to show that such faith-based organizations are able to help managing the social issues in the society. To gain a sustainability status, ZDOs need to formulate strategies that may help them in 
reaching that status. The first step in the effort to design a strategic plan is to identify strengths, weaknesses, opportunities and threats in the ZDOs. Thus, collecting data and information on organizational strengths, weaknesses, opportunities, and threats is vital for ZDOs.

There are four aspects worth investigating; they are strengths, weaknesses, opportunities and threats of the organizations. The study thus attempted to answer the following research questions:

1. What are the organizational strengths of ZDOs in Malaysia?

2. What are the weaknesses of ZDOs?

3. What are the organizational opportunities available of ZDOs in Malaysia?

4. What are the threats faced by ZDOs?

The findings of the study are expected to give insight to ZDOs on their current strengths, weakness, opportunities, and threats. The findings are also expected to provide information to the ZDOs in Malaysia so that they can take proactive measures to change, improve, and develop themselves in the future; and that such problems (weaknesses and threats) can be systematically eliminated. The findings can be taken into consideration in designing strategic way forward plan for $Z D O S$ operation. This may help ZDOs to maintain, to improve, and to gain sustainability by fully utilizing the strengths and available opportunities as well as to be able to achieve their goals.

\section{Organizational strengths, weaknesses, opportunities, and threats of ZDOs: A literature review}

Although there have been many studies conducted on faith-based organizations and ZDOs, none has been done to specifically focus on their strengths and opportunities. The findings also indicate that there were not many research conducted concerning on the weaknesses and threats of ZDOs. The absence of such work provides vacuum of references in relation to the aspects which should be leveraged and avoided by organizations of such sort The majority of the research have focused on the general issues and concerns of ZDOs. Furthermore, most of the researches are conducted by using quantitative rather than qualitative method. Relevant literatures were reviewed in order to understand the current situation of the organizational strengths, weaknesses, opportunities and threats faced by faith-based organizations in general, and ZDOs in specific.

The review shows that most of the researches have focused on certain (a) processrelated aspects, for example about the effective financial management (Muhammad, 2019; Noor et al, 2015), or stakeholders' aspects such as the attitude of zakat recipients (Halim et al., 2012). Both aspects provide inputs which indicate the strengths and opportunities; or weaknesses and threats of ZDOs. The term organizational strengths and organizational opportunities; and weaknesses and threats denote two different themes about 
organizations' characteristics. This paper differentiates 'strengths and weaknesses' from 'opportunities and threats' in that the former are considered as internal aspects of the organizations while the latter are considered as external environment that affect the organizations; and could be leveraged or avoided by the organizations, respectively (Modrak et al., 2011). The review of literature on the four aspects is presented below:

\section{Strengths}

\section{Strong strategic network}

Research Mburu (2011) mentioned that faith-based organizations often have a strong networking with other organizations in order to increase support of its services and provide accessibility to the services among targeted recipients. Hamilton (2011) mentioned that there is a knowledge-sharing opportunities existing in faith-based organizations, whether it is via trainings and conferences or through on the job trainings, which is open to volunteers for instance. This suggests that faith based organizations are very likely to form strong networking with other organizations or with individuals. Such is the case because of their willingness to provide learning opportunities for the staff members of other organizations.

\section{Effective financial management}

A unique strength which is usually found in ZDOs is the effective financial management (Noor et al, 2015). This is due to the fact that the management of zakat is directly associated with the Islamic duty. Belarbi (1992) stated that although zakat is considered as an economic variable, it is also considered as a mean for religious purification and religious obligations among Muslims. Thus, the distribution of zakat funds and the overall financial management of ZDOs are given significant attention, and are managed with high integrity hence is free from irregularities. Failure to honour the integrity when managing the fund is linked to the negative implications as it is elaborated in the teaching of Islam.

\section{Opportunities}

\section{Assistance for zakat recipient}

There are programmes on the development of knowledge and technology among zakat participants. These are opportunities that can be leveraged by faith based organizations. Noor et al (2015) mentioned that the programmes could enhance the efforts to improve the life quality among zakat recipients. Nurzaman (2011) mentioned that in Indonesia, the health quality of zakat recipients is low, thus, ZDOs could pay more attention into this matter for example by providing facilities and programmes related to health improvement. Asomugha et al (2011) believed that faith-based organizations can be the agents in promoting health and well-being in the community.

\section{Advancement in knowledge and technology}

Various developments in knowledge and technology also provide opportunities which 
can be utilized by faith based organizations or ZDOs to improve their effectiveness. Wahab \& Rahman (2011) as well as Jurini (2013) mentioned that adopting and applying advance information and communication technological (ICT) in the operation, along with adapting right values and system and having trained staffs, may help ZDOs to upgrade their services. In addition, ZDOs can also adopts ICT to identify eligible zakat recipients in order to ensure the effectiveness of the distribution pattern (Halim et al., 2012).

\section{Weaknesses}

\section{Weaknesses of zakat managers}

The weaknesses in managing the zakat funds include the personnel issues. Managers in ZDOs who do not have relevant educational background pose a crucial limitation in managing ZDOs. Lubis et al (2011) and Dahan (1998) also attribute the weaknesses to the shortage of staffs in addition to lack of experts in the ZDOs. The existence of deviant performance in the ZDOs (abuse of power and breach of trust) have resulted in negative perception of the public towards the ZDOs.

\section{Weaknesses in the distribution of zakat fund}

A lot of problems have been reported on zakat distribution (Yusof, 2010). Rahman et al (2012); Lubis et al (2011) found that the cause of ineffectiveness of zakat fund distribution is the inabilities of ZDOs to properly recognize the zakat recipients.

\section{Weaknesses in identifying eligible recipients}

Rahman et al (2012) found that in some cases, zakat has not been handed over to the rightful persons. Lubis et al (2011) found that there have been cases when zakat application form being sold illegally by certain irresponsible individuals to the potential zakat recipients. Thus, this would make the asnaf (people who are eligible to receive zakat) to miss the zakat registration system.

\section{Gap between zakat payment time and zakat disbursement time}

Another reason for the lower performance of zakat distribution is related to the delayed zakat payment by zakat payers. Some zakat payers choose to pay zakat at the year-end while the disbursement has been made before the zakat collection. To some extent, paying zakat at the end of the year does not help ZDOs to distribute the fund in the same year (Noor et al., 2015). Hasan (1987) stated that zakat funds must be disbursed as immediately as possible, and there should not be any delay because the funds are the rights of zakat recipients who might be badly in need of assistance. Lubis et al (2011) found that some ZDOs face the shortage of zakat fund while some have the surplus. This is one of the issues that has decreased the performance of zakat distribution among ZDOs.

\section{Negative public perception on zakat management}

Noor et al (2015) stated that there were reports on alleged mismanagement of zakat 
fund which lead to the skeptic attitudes among zakat payers. Wahid et al (2009) stated that managing zakat funds involves the distribution of zakat funds to its eligible recipients, and the management of its surplus in a financial year. There are perception among zakat payers in relation to the management of the surplus fund, i.e the way ZDOs manages the surplus fund after zakat has been distributed to eligible recipients. The negative perception may decrease their trust to ZDOs, resulting in their less willingness to pay zakat to ZDOs.

\section{Bureaucracy}

There are reports on difficulties to deal with the tedious procedures implemented by ZDOs. According to Salleh (2004), zakat application procedure sometimes caused obstacle to the zakat recipients particularly when they feel there is an extent of disruption to their dignity or invasion of privacy. It occurs when they have to disclose information, which they regard as very personal. Disclosing the information to the ZDOs officials is like disclosing it to the public.

\section{Threats}

\section{External interference}

Among the challenges faced by ZDOs are political interference and state structural reforms (Schaeublin \& Frazen, 2012). For instance, after the structural reforms in West Bank and the Gaza Strip in 2009 and 2010, respectively, the funding towards ZDOs declined. This was due to the changes in the political climate in the country. The post-reform changes have caused the community to lose trust in the ZDOs; it indicates the importance of political situation in determining the perception of the community toward the operation of ZDOs.

\section{Attitude of zakat payer and recipients}

According to Ndiaye (2007), there are some threats to the ZDOs which originate from the zakat payers themselves. For instance, there are some Muslims who are reluctant to give zakat because they fear reprisals by the authorities. They have asked zakat organizations to confirm the destination of their zakat, which they pay in lieu of their annual income tax. Hasan (1987) found that there is still a widespread practice by certain group of zakat payers to pay zakat to various categories of people whom they consider as eligible zakat recipients instead of giving it to ZDOs. This practice reflects the fact that people do not have full trust in ZDOs which are in charge of collection and disbursement the zakat funds. Ahmad et al (2006) found that if zakat payers pay directly to asnaf, it may affect the operation of ZDOs, both in terms of collection as well as the distribution of zakat funds. In effect, less amount of zakat will be collected, and in turn less number of recipients could get the benefit from zakat distribution. If persisted, the situation may impede the role of ZDOs as organizations that help the poor and needy people. 


\section{Time consuming of zakat application process}

Bad experiences by zakat recipients with the zakat authorities could discourage them from making application for zakat (Salleh, 2004). Among the bad experiences is the long period of time taken by ZDOs before the application status is informed to the applicants.

\section{Dependent zakat recipients}

Rahman et al (2012) found that if ZDOs continuously help the asnaf, it would create their dependency on zakat recipients which would not help them in changing their lifestyle, or enhancing their standard of living. Therefore, the mechanism to give financial assistance should be changed such as by sending them to training centres so that they can gain certain skills; hence equipping them with enabling skills which would improve their employability.

The above literature identified several strengths and weaknesses of ZDOs that address issues on the distribution of zakat fund, personnel capability, and the bureaucracy within the ZDOs. It also listed the opportunities to be leveraged, or threats to be managed. This research was conducted to identify the four organizational aspects in a ZDO in Malaysia.

\section{Method}

\section{Participants}

Responses on the strengths, weaknesses, opportunities and threats of ZDOs are gathered from participants who are the employees of an organization which main functions are zakat distribution and life sustainability programmes. The term zakat distribution organizations or ZDOs will be used to represent the selected ZDO befitting the confidentiality clause in the consent agreed by the participants. A total of 16 participants participated in the study, consisting of 5 management officers and 11 staff members.

\section{Research design}

The objective of this research is to obtain an in-depth information about the strengths, opportunities, weakness of, and threat faced by, ZDOs. Adopting developmentorientated and problem-orientated analysis, qualitative research design was used as a main method to obtain the information. Multiple methods were adopted to gather information, which are via (a) Focus Group Discussion (FGD) which was conducted to collect data from the ZDOs employees on the organizational strengths, weaknesses, opportunities, and threats. The FGD allowed the participants to freely and extensively express their view, at the same time allowed the other members to contribute their opinion during the discussion (Howitt, 2013); (b) Document analysis was conducted to get the background information of the organizations' current situation, including the strengths, opportunities, weaknesses, and threats related to their work plan, resources, staffing and activities. 


\section{Procedure}

Theresearchers analysed various documents that the organization had allowed them to go through, such as the strategic plan document. The researchers conducted a three-hour focus group discussion session with the employees of aZDO to gather relevant information. All employees participated in the session and cooperated well with the researchers in providing relevant information. Before the session started, the participants were briefed on the objectives of the research. The participants gave their informedconsent by signing in a specific form.

The sessions were divided into two; the first session was to obtain information regarding the current condition of the organization by using the SWOT matrix. The FGD began with the researchers distributing the post-it notes to each participant. The strengths, weaknesses, opportunities and threats of the ZDO were asked to the participants. The participants wrote down their responses on the notes. Once completed, the researchers compiled and categorized the points they wrote according to the four categories. In the second FGD which was conducted on the next day, the same participants were shown the compiled responses according to strengths, weaknesses, opportunities, and threats. The objective of the second FGD was to verify the categorized responses with all participants, avoiding the risk that the result is based on certain employees' personal judgment and opinion.

\section{Questions of FGD}

In the first session, the researchers gathered essential information by placing relevant questions that facilitate the participants to indicate the strengths, weaknesses, opportunities and threat of the $Z D O$. The questions are:

1. Could you tell us about your organization in general?

2. In your opinion, what are the strengths of your organization?

3. What are the weaknesses of the organization?

4. In your opinion, what are the opportunities that are available for your organization?

5. What are the threats encountered by the organization?

6. What make you feel satisfied with your organization?

7. How to improve the performance of your organization?

8. What makes you feel dissatisfied with the organization?

9. What can the organization do to overcome the dissatisfaction experienced by the employees?

10.What do you suggest for the organization to perform better in the future?

\section{Data analyses procedure}

The data gathered from the two FGD sessions were analysed by using thematic analysis. The researchers itemized and grouped the responses according to the 
themes which are in tandem with the research objectives. Data obtained from the document analysis was used as complementary information to the main findings; to be used as supportive evidence to the main findings. The results were then shared with the participants in order to check whether the data and grouping were reflective of their views on the organization, not only based on a certain employee personal judgment and opinion.

\section{Results}

The objectives of the study are (a) to find out the organizational strengths of ZDOs; (b) to investigate the weaknesses of ZDOs; (c) to find out the organizational opportunities that can be leveraged by ZDOs; and (d) to explore the threats faced by ZDOs. The findings provide bases for the development-orientated and problemorientated analyses of the ZDOs. Based on the focus group discussion as well as document analysis, the following findings have been found:

\section{Table 1}

Strengths, Weaknesses, Opportunities and Threats of ZDO

\begin{tabular}{ll}
\hline Strengths & Good human resource management \\
& Stable financial capacity \\
& Availability of vast network; \\
& Good organization setup; \\
& Positive work culture; \\
& Good learning and development environment. \\
& Workplace-related matters, personnel/staff issue, \\
& Management-related issues. \\
\hline Weaknesses & Conducive external environment of ZDO, \\
& Proactive distribution of zakat funds, \\
& Available collaboration with other agencies. \\
\hline Threats & Non-supportive environment, \\
& Attitude of zakat recipients and applicants, \\
& Competition from outside parties, \\
& Public dependency, \\
External interference.
\end{tabular}

Details of the findings are deliberated below

\section{Strengths}

\section{Workforce}

It was found from the ZDO documents that employees in the organizations adopt high level of professionalism in completing their assigned tasks. The staff members are led by a caring general manager which indicates the presence of good top-down communication in the organization. Besides, they have been found to be talented, skilful, and are committed to improve the 
organizations. In fact they are capable employees who should be maintained and developed. If their competencies are matched with several development opportunities, the employees may help the organizations to perform better.

\section{Stable financial sources}

The FGD participants believed that the organization is in a good and stable financial position. As found in the document analysis result, they also mentioned that the stable financial sources allowed the organization to conduct various planned programmes. They mentioned that they have a stable amount of fund to be distributed to the recipients throughout the country. The financial stability can be attributed to the nature of the organization which is characterised by faithful zakat payers who believe that zakat is a religious responsibility which they must observe.

\section{Vast network}

Vast network is believed to be one of the strengths that become the benefit for the ZDOs. The FGD participants viewed that the organization has a good relationship with the ministry which is in charge of zakat collection, the non-government and private organizations. This network helps the organization in maintaining the zakat funds sources, in managing the zakat funds distribution, and in conducting the development programmes for zakat recipients or for community members. It provides more accessibility to potential zakat recipients.

\section{Organization setup}

The organization's setup has been regarded as one of the organization's strengths. Its facilities support employees in performing their tasks. The location of the ZDO office building which is in a strategic location provides easy access for the staffs and clients. The office equipment, to certain extent, provides conveniences and comforts to the employees. These factors are essential to create positive working atmosphere. In short, the organization provides attractive remuneration scheme for the employees. Aside from it, the organization also allows the employees to do field programmes other than routine tasks in the office. These are important stimuli which drive them to have a good job performance.

\section{Work culture}

Positive work culture has been identified as a strength for organization. It is associated to many factors, including a good cooperation among employees; and a good work relationship with their superiors. They also reported their willingness to perform tasks, duties, and responsibilities which are beyond their job description. They are willing to help each other in completing the assigned tasks. Beside the task accomplishment, they uphold the culture of professional development which enables them the opportunities for continuous career development. 


\section{Learning and development}

The employees believed that they have the opportunity to develop themselves while working in the organization. For example, one of the employees mentioned that the employee movement in the organization is dynamic; it makes them possible to move from one department to another; or be ready to help others with various kinds of work type. Thus, it became an opportunity for them to learn the new skills and knowledge. The employees also experienced indirect learning process through various programmes that they conducted. Besides that, the organization also encourages and sponsors the employees to attend trainings, to equip them with necessary skills and knowledge.

\section{Weaknesses}

\section{Work place}

The FDG gathered information from the members that employees in the ZDO are having difficulties with their current workplace; most of the time it can cause pressure for them. One of the difficulties faced by the employees in the ZDO is the limited and less conducive office space. The ZDO is renting one of the buildings located in downtown Kuala Lumpur. In effect, the employees reported that their work performance and productivity fluctuate. They are of the view that if the workplace could be improved then their working performance and productivity could be increased.

\section{Staff members}

Two issues have been identified on the ZDO workforce; first is the lack of staff; and second is their work skills inadequacy. The first aspect has caused a number of negative outcomes such as late the distribution of zakat funds to the recipients and also difficulties in running the planned activities. Besides, due to the small number of staff, each staff had a huge pressure of tasks, duties, and responsibilities, and it caused many of them to deal with the work overload. The problem could get worse when they need to go for the field work assignment, leaving behind the unattended work at the office. Regarding to the work skills inadequacy, some of the ZDO staffs do not have the match specification with the job description of their position.

\section{Zakat management}

The weakness of ZDO is also attributed to the absence of management support systems (database system, systematic correspondence, application procedure and filing system) as well as the tedious zakat application procedure. The former has caused limited functionality of ZDO while the latter is associated with the absence of flexibility in the organization; and difficulties for applicants to check the status of their zakat application or to update their form. The tedious application procedure is because it takes a long time to get the application approval. It usually takes one to two weeks, which is not convenient for the zakat applicants 
who are in dire need of financial support. It created bad experience to the zakat applicants and it leads them to feel discouraged making another application in the future. The FGD participants are of the view that online application and database system will allow fast and direct communication between the ZDO and applicants, hence eliminate the time consuming process.

\section{Opportunities}

\section{External environment}

The FGD participants reported some external environment which can be leveraged in order to improve the ZDO's performance. They indicated that the plan to expand the office or relocate it to the more strategic place will be possible if the organization takes advantage of the available opportunities (to consider moving to a more spacious office site). When the organization realizes it, it is expected to improve and strengthen the function and performance of ZDO.

\section{Proactive distribution of zakat}

There are various opportunities that can be leveraged by ZDO in order to be more proactive in distributing zakat funds. The stable financial capacity also allows it to proactively look for eligible long-distance recipients, i.e recipients who stay in states beyond the ZDO is located.

\section{Collaboration with other agencies}

Various programmes can be conducted with other companies which have the willingness to join-force with ZDO in distributing zakat. The FGD participants indicated that the ZDO has an existing stable networking chain, but they believed that there is still opportunity to build wider extent of networking with other organizations. A more efficient collaboration or joint venture activities with non-government agencies at the national and international level could be explored in order to diversify the mechanisms to disburse zakat fund, or to conduct educational programmes for the society.

\section{Threats}

\section{Environment}

External environmental factors such as intense rainfall in the ZDO office site and certain negative behaviors of clients (e.g sexual harassment) are associated with the threats identified by the employees. According to them, each year they have to face flash flooding due to the bad drainage system. It prevents them from working during flash flood because the employees cannot access the work place; and it also ruins the documents in the office. It has caused damages to their facilities such as furniture and official cars as well. Regarding the sexual harassment case, though it is an isolated issue, the absence of security personnel has made it difficult for the ZDO to enhance its safety and security aspects.

\section{Zakat recipients}

Every day the ZDO deals with zakat recipients whose background vary, some of 
them are impatient and angry when dealing with ZDO employees. They became impatient or angry due to the insufficient facilities and staffs to serve the high turn-ups of applicants. The negative experience encountered by the zakat recipients could discourage them from dealing with the organization in the future.

\section{Reputation of ZDO}

The widespread of negative issues associated with the organization is one of the threats that the organization faces. This includes an allegation towards the organization regarding its inability to manage zakat fund. As it is stated in the literature, alleged mismanagement of ZDO would cause of skeptic attitudes among zakat payers (Noor et al., 2015). It may deteriorate the level of trust among zakat payers towards the organization, or in another word it can increase their negative perceptions towards zakat institution.

\section{Public dependency}

It is found that one of the roles of the ZDO is to strengthen the socio-economic condition of the Muslim community in Malaysia. This problem is continuously addressed through community development activities with both governmental and non-governmental organizations. Besides, the ZDO also provides financial aids to individuals who are in need of assistance. Nevertheless, this has turn out to be a negative consequence when many of them would regard the ZDO as their permanent funds provider. The public dependency on the ZDO could be regarded as a threat because the mission of ZDO is to provide initial support for the individual or organization instead of making them permanent recipients of the zakat funds. As for the recipients, they have developed a mindset that the ZDO is obliged to approve their application, and thus reducing their efforts to find alternative sources of fund.

\section{External interference}

The FGD participants indicate that there are occasions when external parties disrupt in the management of the organization or in its work processes. They consider that all work processes must be in accordance with the policies and directions which are stipulated by the main organization. This, to some extent, prevents them to enact improvements when handling unique issues; and this contributes to ineffective operation of the organization.

This study is not without limitations. First, this study only focused on one ZDO in Malaysia, thus the generalization of the findings must be done carefully. There is also a probability that some aspects are unique and occur in the observed ZDO only. For example, it was found in previous studies that ineffective distribution of zakat is caused by the lack of abilities to properly identify zakat recipients (Lubis et al., 2011; Rahman et al., 2012; Salleh, 2004). However, the current report showed that the inefficiency is due to two factors, i.e., the absence of management support systems and tedious application procedure. Literature had 
reported that zakat management organization received negative perception (Yusof, 2010) and dissatisfaction (Wahid et al, 2009) among the payers. Nevertheless, based on the observation made while conducting FGD, some of the employees showed hesitation in expressing views on the discussed issues, limiting the effort to gather adequate information on issues and challenges faced by ZDO. Thus, the data collected may not be as clear as it is expected.

The findings from the SWOT analysis provide broader evidences which serve as essential bases in formulating strategic way in making progress for the ZDO. The available research, such as by Yusof (2010) and Wahid et al (2009) provide information on weaknesses, and threats based on the analysis of ZDO annual report, while the current study derived the strengths, opportunities, weaknesses, and threats of the analysed ZDO from both document analysis and from focus group discussion. The organization can use it to formulate strategies for enhancing its performance and for improving its sustainability. The information also drives the design of interventions for action plans that the organization may take in order to maintain or to enhance its strengths and leverage on the opportunities; or to manage the weaknesses and also to avoid the threats. For example, the current report showed that the ZDO has weaknesses such as the absence of management support systems and tedious application procedure which may cause ineffective distribution of zakat. Interventions such as techno-structural and human process intervention (Cummings \& Worley, 2017) can be implemented as the action plans to manage the identified weaknesses.

\section{Conclusion}

It could be concluded from the above report that ZDOs have various strengths and opportunities, which can be further improved and leveraged, in order to increase the organizations' performance. The report also indicated that the organizations face some weaknesses and threats and by identifying them, it allows the organizations to strategically select on aspects that require more attention. In addition, these aspects are important as they also provide functional understandings about the current position of ZDOs in Malaysia. The information collected from SWOT analysis provides valuable insight for the management, e.g. to leverage or to avoid certain aspects (Modrak et al., 2011), to systematically and practically assess the organizations' capacities for improvement in current environment where technology and societal structure are increasingly changing.

\section{Suggestion}

Future research may involve other organizations with similar functions to get a better understanding of ZDOs. Future research could also engage multiple methods to analyse the organizations in order to provide more insights and understanding of current position 
of zakat service and ZDO strategic. Such studies are essential in order to provide a comprehensive understanding about the overall delivery service of the ZDOs and may be able to improve the overall performance of ZDOs.

\section{References}

Ahmad, S., Wahid, H., \& Mohamad, A. (2006). Penswastaan institusi zakat dan kesannya terhadap pembayaran secara formal di Malaysia. International Journal of Management Studies, 13(2), 175-196. http://www.ukm.my/hairun/kertas kerja/ijms-uum.pdf?ebookid=691

Akanni, A. A. (2006). Profiling a model for the administration of zakat in a multireligious society: The case of SouthWestern Nigeria. Journal of Philosophy and Culture, 3(2), 129-150. https:// doi.org/https://doi.org/10.5897/ JPC2006.00014

Asomugha, C. N., Derose, K. P., \& Lurie, N. (2011). Faith-based organizations, science, and the pursuit of health.Journal of Health Care for the Poor and Underserved, 22(1), 50-55. https:// doi.org/10.1353/hpu.2011.0008

Bakar, M. H. A., \& Abd.Ghani, A. H. (2011). Towards achieving the quality of life in the management of zakat distribution to the rightful recipients (the poor and needy). International Journal of Business and Social Science, 2(4), 237-245. http:/ / i j bs s n e t. co m / journals / Vol__2_No._4;_March_2011/27.pdf

Belarbi, A. (1992). Towards an Islamic economic system. University of Cincinnati.

Cummings, T. G., \& Worley, C. G. (2017). Organization development and change. Cengage Learning.

Dahan, M. (1998). Zakat management and administration in Malaysia. International Conference of Zakat and Taxation.
Fagan, P. F. (2006). Why religion matters even more: The impact of religious practice on social stability. http:// s3.amazonaws.com/thf_media/2006/ pdf/bg1992.pdf

Hafsi, T., \& Thomas, H. (2005). Strategic management and environments: The case of a philanthropic organization. VOLUNTAS: International Journal of Voluntary and Nonprofit Organizations, 16(4), 329-351. https://doi.org/ $10.1007 / \mathrm{s} 11266-005-9146-\mathrm{y}$

Halim, H. A., Said, J., \& Yusuf, S. N. S. (2012). Individual characteristics of the successful asnaf entrepreneurs: Opportunities and solutions for zakat organization in Malaysia. International Business and Management, 4(2), 41-49. https://doi.org/http:dxdoi.org/10.3968/ j.ibm.1923842820120402.1040

Hamilton, M. (2011). The impact of organizational culture on communities of practice within a faith-based organization. In ProQuest Dissertations and Theses database. UMI.

Hasan, N. M. N. (1987). Zakat in Malaysia present and future status. IIUM Journal of Economics and Management, 1(1), 47-75. https://econpapers.repec.org/ RePEc:ije:journl:v:1:y:1987:i:1:p:47-75

Howitt, D. (2013). Introduction to qualitative methods in psychology. Prentice Hall.

Johari, F., Ab. Aziz, M. R., Ibrahim, M. F., \& Mohd Ali, A. F. (2013). Zakat distribution and programme for sustaining muallaf belief and thought. Jurnal Teknologi, 66(1). https://doi.org/10.11113/jt.v66.1940

Jurini, M. D. (2013). Common weaknesses by zakat collecting organization: A study of instilling the concept of values-driven Organization. Open Journal Systems, 2(4), 1-2.

Kong, L. (2014). Rise in number of homeless people in Kuala Lumpur. In The Straits Times. http://www.straitstimes.com/ the-big-story/asia-report/malaysia/ 
story/rise-number-homeless-peoplekuala-lumpur-20140608 on June 12, 2015

Lubis, M., Yaacob, N. I., Omar, Y., \& Dahlan, A. A. (2011). Enhancement of zakat distribution management system: Case study in Malaysia. International Management Conference (IMAC 2011).

Mburu, P. W. M. (2011). The role of faith based organizations in the delivery of urban services to the poor.

Modrak, V., Dima, I. C., \& Man, M. (2011). Methodical approach to corporate sustainability planning. Polish Journal of Management Studies, 3, 156-166.

Mohammed, Y. (2011). Zakat expenditure, school enrollment, and economic growth in Malaysia. International Journal of Business and Social Science, 2(6), 175181.

Muhammad, I. (2019). Analysis of zakat system in high-income islamic countries. The Journal of Muamalat and Islamic Finance Research, 16(2), 1-11. h ttps://doi.org/10.33102/ jmifr.v16i2.219

Ndiaye, A. (2007). Islamic charities in Switzerland and the practice of zakat.

Noor, A. H. M., Rasool, M. S. A., Ali, R. M. Y. S. M., \& Rahman, R. A. (2015). Efficiency of Islamic institutions: Empirical evidence of zakat organizations' performance in Malaysia. Journal of Economics, Business and Management, 3(2), 282-286. https:/ /doi.org/10.7763/JOEBM.2015.V3.195

Nurzaman, M. S. (2011). Zakat and human development: An empirical analysis on Poverty alleviation in Jakarta, Indonesia. 8th International Conference on Islamic Economics and Finance.

P, A. K., \& Umah, U. K. (2011). Penerapan akuntansi zakat pada lembaga amil zakat (studi pada LAZ DPU DT Cabang Semarang). Jurnal Bisnis Dan Manajemen, 7(2), 68-97.
Rahman, A. A., Alias, M. H., \& Omar, S. M. N. S. (2012). Zakat institution in Malaysia: Problems and issues. GJAT, 2(1), 35-41. http://www.gjat.my/gjat062012/ gjat1220120201.pdf

Salleh, M. S. (2004). Lokalisasi zakat: Satu cadangan teoritis. Hailani Muji Tahir, Abdul Ghafar Ismail and Zamzuri Zakaria (Eds.), Prosiding Muzakarah Pakar Zakat, Bangi, Selangor Darul Ehsan, 105-117.

Sarea, A. (2012). Zakat as a benchmark to evaluate economic growth: An alternative approach. International Journal of Business and Social Science, 3(18), 242-245.

Schaeublin, E., \& Frazen, O. (2012). Charity under threat? Zakat institutions in the occupied Palestinian territory ( $\mathrm{p}$. 147785).

Thomas, M. L. (2008). Faith-based organizations and legislative advocacy: $A$ qualitative inquiry [Virginia Commonwealth University]. http:// scholarscompass.vcu.edu/cgi / vi e w c on tent.cgi ? article= 2328\&context=etd

Wahab, N. A., \& Rahman, A. R. A. (2011). Efficiency of Zakat institutions and its determinants. 8th International Conference On Islamic Economic and Finance. http://www.iefpedia.com/ english/wp-content/uploads/2011/12/ NORAZLINA_ABD._WAHAB.pdf

Wahid, H., Ahmad, S., \& Kader, R. (2009). Pengagihan Zakat oleh Institusi Zakat di Malaysia: Mengapakah masyarakat Islam tidak berpuashati? Jurnal Syariah, 17, 89-112.

Widiastuti, T., Mawardi, I., Robani, A., \& Rusydiana, A. S. (2018). Optimization of Zakat fund management in regional Zakat institution. Humanities \& Social Sciences Reviews, 6(2), 133-139.

Worldbank. (2015). World development indicators. data world bank. http:// 
data.worldbank.org/country/Malaysia on June 12, 2015

Yusof, M. I. M. (2010). Pengurusan zakat di negeri Selangor: Mengorak langkah meneraju perubahan. http://www.e$\mathrm{z}$ a kat.com . my / w p - content/ files_flutter/ 1293695325PaperLZS_ KonvensyenUSM2DIS092010.pdf

Received 31 January 2021

Revised 22 April 2021

Accepted 31 July 2021 
